\title{
Immunological Detection of endo Polygalacturonase Secretion by Fusarium oxysporum in Plant Tissue and Sequencing of Its Encoding Gene*
}

\author{
Tsutomu ARIE**, Satyanarayana GouTHU**, Satoshi SHIMAZAKI***, \\ Takashi KAMAKURA**, Makoto KIMURA**, Mitsuko INOUE ${ }^{\dagger}$, \\ Koji TAKIO**, Akira OZAKI**, Katsuyoshi YONEYAMA $^{\dagger}$ \\ and Isamu YAMAGUCHI**
}

\begin{abstract}
Fusarium oxysporum, a soilborne phytopathogenic fungus, produces endopolygalacturonase (PG) which has been suggested to be related to disease development. A polyclonal antibody (PAb) APG1 was prepared against purified $\mathrm{PG}$ from $F$. oxysporum f. sp. lycopersici race 2. By direct tissue-blotted immunobinding assay (DT-IBA) with the antibody, PG production by the pathogen in the stem of the host plant was confirmed. Degenerate primers were designed based on partial amino acid residue information for the PG protein from the fungus: part of the PG-encoding gene was obtained by PCR. Using TAIL-PCR, the complete gene encoding PG was cloned and sequenced. The structural gene comprises 1318 bp coding for 371 amino acids with a putative signal peptide of 22 amino acids, and the open reading frame is interrupted by four introns of $47,51,50$, and $54 \mathrm{bp}$. The deduced amino acid sequence of the mature protein showed $82.9,29.0,27.6,14.2$, and $26.9 \%$ homology with those of $F$. moniliforme PG, Cochliobolus carbonum PGNI, Aspergillus niger PG, A. oryzae PG, and Sclerotinia sclerotiorum PGI, respectively.
\end{abstract}

(Received June 12, 1997 ; Accepted October 16, 1997)

Key words : antibody, DT-IBA, pectin degradation, Fusarium oxysporum f. sp. lycopersici, endopolygalacturonase (PG), nucleotide sequence.

\section{INTRODUCTION}

Fusarium oxysporum Schlechtend.: Fr. is one of the most economically important soilborne pathogenic fungi in both temperate and tropical regions. The failure to control the disease despite the use of many conventional methods such as chemical fungicides, biocontrol agents, soil amendments, and resistant cultivars could be due to the poor understanding of the mechanism of disease development and the physiology and biochemistry of the pathogen.

Three stages have been proposed in Fusarium disease development ${ }^{4)}$. First, the pathogen invades roots of host plants. Second, the mycelia elongates through host cells to reach the stem vessels. During these two stages, cellular degradative enzymes are excreted ${ }^{4}$. The third stage is the appearance of symptoms on host plants.
Some enzymes that digest vessel cell walls and/or toxins that kill cells have been reported to play important roles during the third stage ${ }^{4)}$.

The pectinolytic endopolygalacturonases ( $\mathrm{PGs}$, poly [1,4- $\alpha$-D-galacturonide] glycanohydrolase, EC 3.2.1.15) have been reported as pathogenesis-related proteins which degrade plant cell wall structure, including vessel cell walls. Many species of plant pathogenic fungi and bacteria utilize the enzyme(s) in their offensive arsenal to penetrate and colonize plant tissues during infection $^{12)}$.

Enzymatic analysis has been the usual strategy to study the taxonomy and evolution of pathogenic types such as formae speciales (ff. sp.) or races. However, isoenzymatic analysis of $F$. oxysporum has thus far afforded no clear relationship between isozyme polymorphism and pathogenic forms. We analyzed PG by isoelectric focusing (IEF) and found no differences

* This study was supported in part by a Grant for Scientific Research from the Ministry of Education, Science, Sports and Culture, Japan and a grant for the "Biodesign Research Group" from The Institute of Physical and Chemical Research (RIKEN).

** The Institute of Physical and Chemical Research (RIKEN), 2-1 Hirosawa, Wako 351-0198, Japan 理化学研究所

*** Present address : Kyowa Seed Co., 377 Ozawa, Chonan, Chosei-gun, Chiba 297-0142, Japan 現在：協和種苗 (株)

+ Faculty of Agriculture, Meiji University, 1-1-1 Higashi-Mita, Tama, Kawasaki 214-0033, Japan 明治大学農学部 
between ff. sp. lycopersici (Sacc.) W.C. Snyder \& Hans. and cucumerinum Owen in PG isozyme patterns ${ }^{3)}$.

Recently, a PG protein was purified from $F$. oxysporum f. sp. lycopersici. Its isoelectric focusing showed at least 4 isoenzymes ${ }^{20}$. Di Pietro and Roncero (1996) also reported four forms of the protein, PG1 and three $N$-glycosylated isoforms ${ }^{6}$. According to them, $N$-glycosylation was essential for the secretion of PG. Further, they detected PG1 protein in the stems of tomato plants infected with $F$. oxysporum $\mathrm{f}$. sp. lycopersici whereas a pectate lyase was observed in roots during early stages of infection.

PG genes have been recently cloned and characterized from several species of fungi, including Cochliobolus carbonum Nelson ${ }^{22)}$, Aspergillus niger van Tieghem ${ }^{5,6,21)}$, A. oryzae (Ahlburg) Cohn ${ }^{10)}$, A. flavus Link ex Fries ${ }^{22)}, F$. moniliforme Sheld.5), and Sclerotinia sclerotiorum (Lib.) de Bary in Vergh ${ }^{17}$.

DNA sequence data of $\mathrm{PG}$ gene of $F$. oxysporum could clarify the importance of the gene as a symptom development-related factor and its role in the determination of host and/or symptom induction.

This paper deals with production of an antibody against a PG protein of $F$. oxysporum f. sp. lycopersici, detection of $\mathrm{PG}$ production in plant tissues by DT-IBA, partial amino acid sequencing of the protein, sequencing of the complete gene, and comparison of the amino acid sequences.

\section{MATERIALS AND METHODS}

Fungal isolates and culture conditions Fusarium oxysporum f. sp. lycopersici race 2, 880621a-1 isolated in Imaichi, Tochigi was maintained on potato dextrose agar (PDA) medium.

To purify the endopolygalacturonase (PG) protein, an inducing medium made of $0.09 \%(\mathrm{w} / \mathrm{v}) \mathrm{NH}_{4} \mathrm{H}_{2} \mathrm{PO}_{4}, 0.2 \%$ (w/v) $\left(\mathrm{NH}_{4}\right)_{2} \mathrm{HPO}_{4}, 0.047 \%(\mathrm{w} / \mathrm{v}) \mathrm{MgSO}_{4}, 0.05 \%$ (w/v) $\mathrm{KCl}$, and $1.0 \%(\mathrm{w} / \mathrm{v})$ pectin (from citrus fruit, Sigma Chemical Co., St. Louis, MO, USA) was used ${ }^{21)}$ to culture F. oxysporum $880621 \mathrm{a}-1$ at $25^{\circ} \mathrm{C}$ for 40 days.

$P G$ purification and determination of $P G$ activity $\quad \mathrm{PG}$ was purified from the culture filtrate of $F$. oxysporum 880621a-1 grown on the inducing medium in three steps, as follows. Three liters of culture suspension was filtered through Toyo No. 2 paper to remove fungal matter. The filtrate was $40 \%$ saturated with ammonium sulfate and centrifuged at $10,000 \times g$ for $15 \mathrm{~min}$ to remove the precipitate. The supernatant was then $90 \%$ saturated with ammonium sulfate and centrifuged to collect the precipitate containing the PG protein. The precipitate was suspended in $0.1 \mathrm{M}$ sodium acetate buffer (AcB, pH 4.0) and subjected to gel filtration on Sephadex G-25 Coarse (Pharmacia Biotech, Uppsala, Sweden) followed by ion exchange on SP Sephadex C-50 (Pharmacia Biotech). The active fraction was then concentrated by ultra filtration with Centriprep-3 (Amicon, Beverly, MA, USA) and gel filtrated again with
Sephadex G-75 (Pharmacia Biotech). All steps in the chromatography procedure were performed at room temperature. Protein concentrations were measured using Protein Assay reagent (Bio-Rad Laboratories, Hercules, CA, USA) according to the manufacturer's protocol.

PG activity was monitored by measuring the release rate of reducing sugar in enzyme-substrate reaction mixture using a modified DNS test ${ }^{12}$. Five-hundred $\mu 1$ of each fraction was mixed with $50 \mu$ l of the substrate solution, $0.5 \%(\mathrm{w} / \mathrm{v})$ polygalacturonic acid in AcB. After $30 \mathrm{~min}$ incubation at $25^{\circ} \mathrm{C}, 0.2 \mu \mathrm{l}$ of $6.85 \mathrm{M}$ potassium ferricyanide was added, and the mixture was immediately put in a $95^{\circ} \mathrm{C}$ water bath for $30 \mathrm{~min}$. The absorbance $(600 \mathrm{~nm} / 405 \mathrm{~nm})$ was determined with a microtiter plate reader. The mixture without incubation at $25^{\circ} \mathrm{C}$ was used as a negative control.

Preparation of antibody against the purified $P G$ Polyclonal antibody against purified $P G$ was raised in mouse following the usual method. One hundred $\mu 1$ of purified PG $(320 \mu \mathrm{g}$ protein $/ \mathrm{ml})$ was mixed with Freund's complete adjuvant or Freund's incomplete adjuvant $(50 \% \mathrm{~V} / \mathrm{v})$ and injected to immunize female mice $(\mathrm{BALB} / \mathrm{c})$ intraperitoneally five times at 2-week intervals. Fourteen days after the final injection, $100 \mu 1$ of purified $P G$ was injected intravenously for boosting. Five days later, orbital blood samples were collected and centrifuged $(10,000 \times g, 10 \mathrm{~min})$ to get antisera. Western blotting analysis was performed to confirm the production of an antibody against PG. An SDS-PAGE gel with the PG sample was transblotted onto a PVDF membrane (BioRad) by semi-dry blotting electrophoresis $\left(2 \mathrm{~mA} / \mathrm{cm}^{2}, 45 \mathrm{~min}\right)$ following the manufacturer's protocol. The blots were recovered and treated with the antibody, secondary antibody (a mixture of biotinated anti-mouse IgM-goat IgG and horseradish peroxidase avidin D), and the substrate solution (2.8 mM 4-chloro-1naphthol in $0.02 \%$ hydrogen peroxide) for immunobinding assay $^{2)}$.

$\boldsymbol{D} \boldsymbol{T}-\boldsymbol{I B A}$ Direct tissue-blotted immunobinding assay (DT-IBA $)^{2}$ was used to examine whether PG was produced in the stem tissues of tomato plants infected with $F$. oxysporum 880621a-1. From 40-day-old tomato plants (cv. Momotaro, Takii Seeds, Kyoto) with and without inoculation, vertical sections were prepared from stems of $c a .1 \mathrm{~cm}$ above the soil surface and put directly on an membrane saturated with Tris buffered saline (pH 7.0) and incubated for $15 \mathrm{~min}$ at room temperature. The membrane was recovered and treated with the PG-antibody as in the immunobinding assay procedure.

Partial amino acid sequencing Purified PG was reduced and $S$-carboxymethylated according to Hirs $(1967)^{9)}$ and digested with Achromobacter Protease I provided by Dr. T. Masaki, Ibaraki Univ., Ami, Ibaraki ${ }^{14)}$. Peptides thus obtained were separated by RP-HPLC on a column of Superspher RP-Select B $(2 \times$ $125 \mathrm{~mm}$, E. Merck, Darmstadt, Germany) using a linear 
gradient of acetonitrile $(0-36 \%$ in $24 \mathrm{~min})$ in $0.1 \% \mathrm{TFA}$ at a flow rate of $0.2 \mathrm{ml} / \mathrm{min}$ with model $1090 \mathrm{M}$ liquid chromatography (Hewlett-Packard Co., Waldbronn, Germany). Methionyl bonds in intact protein were cleaved with cyanogen bromide in $70 \%$ formic acid ${ }^{8)}$ and subjected to gel permeation chromatography on SynChropak GPC-100, -300, and -500 columns $(4.6 \times 250$ mm each, MICRA Scientific, Lafayette, IN, USA) connected in series. The columns were pre-equilibrated with $10 \mathrm{mM}$ phosphate $(\mathrm{pH}$ 6) containing $6 \mathrm{M}$ guanidine hydrochloride and eluted at a flow rate of $0.17 \mathrm{ml} / \mathrm{min}$. Isolated peptides were applied for automated Edman degradation with model 477A Protein Sequencer connected on-line to model 120A PTH Analyzer (PE Applied Biosystems, Foster City, CA, USA). The intact protein was also analyzed to obtain the amino (N)terminal sequence.

Fungal genomic DNA isolation and manipulation Fungal genomic DNA (gDNA) of F. oxysporum 880621a-1 was purified by a miniprep procedure ${ }^{23)}$. DNA gel blots on positively charged Nylon membrane (Boehlinger Mannheium Biochemica, Mannheim, Germany) were prepared by alkaline transblotting, hybridized with a probe prepared using DIG DNA Labeling and Detection Kit Nonradioactive (Boehringer), and detected using the same kit.

Amplification of PG gene by PCR and Thermal Asymmetric Interlaced (TAIL)-PCR Degenerate primers (Table 1) for PCR were designed based on the amino acid sequence data. Primers were dissolved (100 $\mu \mathrm{M})$ in water and stored at $-20^{\circ} \mathrm{C}$. Each PCR reaction mixture contained about $20 \mathrm{ng}$ of gDNA of $F$. oxysporum $880621 \mathrm{a}-1$ in $50 \mu 1$ reaction buffer [ $1 \times \mathrm{PCR}$ Buffer II (PE Applied Biosystems), $0.2 \mathrm{mM}$ dNTPs, $2.5 \mathrm{mM} \mathrm{MgCl}_{2}, 2$ $\mu \mathrm{M}$ of each primer, and $0.025 \mathrm{U}$ AmpliTaq Gold (PE Applied Biosystems)]. Denaturation at $95^{\circ} \mathrm{C}$ for $12 \mathrm{~min}$ was followed by 35 cycles of $94^{\circ} \mathrm{C}$ for $1 \mathrm{~min}, 55^{\circ} \mathrm{C}$ for 30 sec, and $72^{\circ} \mathrm{C}$ for $1 \mathrm{~min}$. Reactions were held at $4^{\circ} \mathrm{C}$ after a final extension at $72^{\circ} \mathrm{C}$ for $10 \mathrm{~min}$. For analysis of PCR products, $10 \mu \mathrm{l}$ of each reaction mixture was subjected to agarose gel (1.2\%) electrophoresis in TAE buffer.

A schematic explanation of TAIL-PCR is shown in Fig. 1. Arbitrary degenerate (AD) primers (Table 1) were prepared according to Liu and Whittier (1995) ${ }^{13)}$ and Arie et al. $(1997)^{1)}$. Primary TAIL-PCR ${ }^{13)}$ reaction mixtures (final volume $25 \mu \mathrm{l}$ ) contained $1 \times \mathrm{PCR}$ Buffer II, $2.5 \mathrm{mM} \mathrm{MgCl}_{2}, 0.2 \mathrm{mM}$ each dNTPs, $0.4 \mu \mathrm{M}$ specific primer, $5 \mu \mathrm{M}$ AD primer (Table 1), $0.016 \mathrm{U}$ AmpliTaq (PE Applied Biosystems), and approximately $20 \mathrm{ng}$ genomic DNA of $F$. oxysporum 880621a-1. The secondary amplification reactions (final volume $50 \mu 1$ ) contained the same components as the primary reactions except that $0.2 \mu \mathrm{M}$ of a nested specific primer (Table 1), $4 \mu \mathrm{M}$ of the same $\mathrm{AD}$ primer as used in the primary reaction and $0.012 \mathrm{U}$ AmpliTaq were used. The template was $1 \mu \mathrm{l}$ of a $1: 50$ dilution of the primary reaction mixture. Thermal conditions for TAIL-PCR were described by Liu and Whittier $(1995)^{13)}$. For analysis of TAIL-PCR products, $10 \mu$ l of each reaction was subjected to agarose gel $(1.2 \%)$ electrophoresis in TAE buffer.

Cloning, sequencing, and analysis of PCR products PCR products were cloned into vector pCR2.1 following recommendations of the supplier (Invitrogen Co., San Diego, CA). TAIL-PCR products were also cloned into pCR2.1 vector directly from the reaction. Clones were selected by colony hybridization using the cloned partial PG gene (amplified with degenerate primers) as a probe. Clones were purified on QIAGEN. Tip 100 columns (Qiagen Inc., Chatsworth, CA, USA) following the manufacturer's recommendation, and the inserts were sequenced using the M13 Reverse or M13 (-40) Forward primers. DNA sequences were determined using Cy5 AutoRead Sequencing Kit (Pharmacia Biotech) and ALFexpress DNA sequencer (Pharmacia Biotech). Sequences were assembled and analyzed using the GeneWorks program (IntelliGenetics, Inc., Mountain View, CA, USA) and Genetyx-Max program (Software

Table 1. Primers used for PCR

\begin{tabular}{|c|c|c|}
\hline Name & Nucleotide sequence $^{\text {a) }}$ & Corresponding genomic location \\
\hline PG1 & 5'-GAYAAYGAYTTYRAYCCBATYG-3' & $\begin{array}{l}\text { bp 336-357, degenerate primer designed based on amino acid } \\
\text { sequence }\end{array}$ \\
\hline PG2 & 5'-CANGTRTTNGTVGGRTARTTRC-3' & bp 1308-1287, degenerate primer \\
\hline PG3 & $5^{\prime}$-AATGCCAAGAGCGGTAGCTTGC-3' & $\begin{array}{l}\text { bp } 674-695 \text { at the nested distal } 5^{\prime} \text { end of the fragment amplified } \\
\text { with PG1 + PG2 }\end{array}$ \\
\hline PG4 & 5'-CTCACTGTTAACAATCTGAG-3' & $\begin{array}{l}\text { bp } 931-912 \text { at the nested distal } 3 \text { ' end of the fragment amplified } \\
\text { with PG1 + PG2 }\end{array}$ \\
\hline PG5 & $5^{\prime}$-ACAGTGAGAATGGATGCC-3' & $\begin{array}{l}\text { bp } 924-941 \text { at the nested distal } 5^{\prime} \text { end of the fragment amplified } \\
\text { with PG1 + PG2 }\end{array}$ \\
\hline PG6 & 5'-GTGAACTGCCTGTGATGTCG-3' & $\begin{array}{l}\text { bp } 623-604 \text { at the nested distal } 3 \text { end of the fragment amplified } \\
\text { with PG1 + PG2 }\end{array}$ \\
\hline N1 & $5^{\prime}$-TGYTGYWSNCARTTYGG-3' & $\mathrm{AD}$ primer for TAIL-PCR \\
\hline TP1 & $5^{\prime}$-NGTCGASWGANAWGAA-3' & $\mathrm{AD}$ primer for TAIL-PCR \\
\hline
\end{tabular}

a) Abbreviations: $Y, C$ and $T ; R, A$ and $G ; W, A$ and $T ; S, G$ and $C ; B, C, G$, and T; V, A, C, and G; N, A, C, G, and T. 


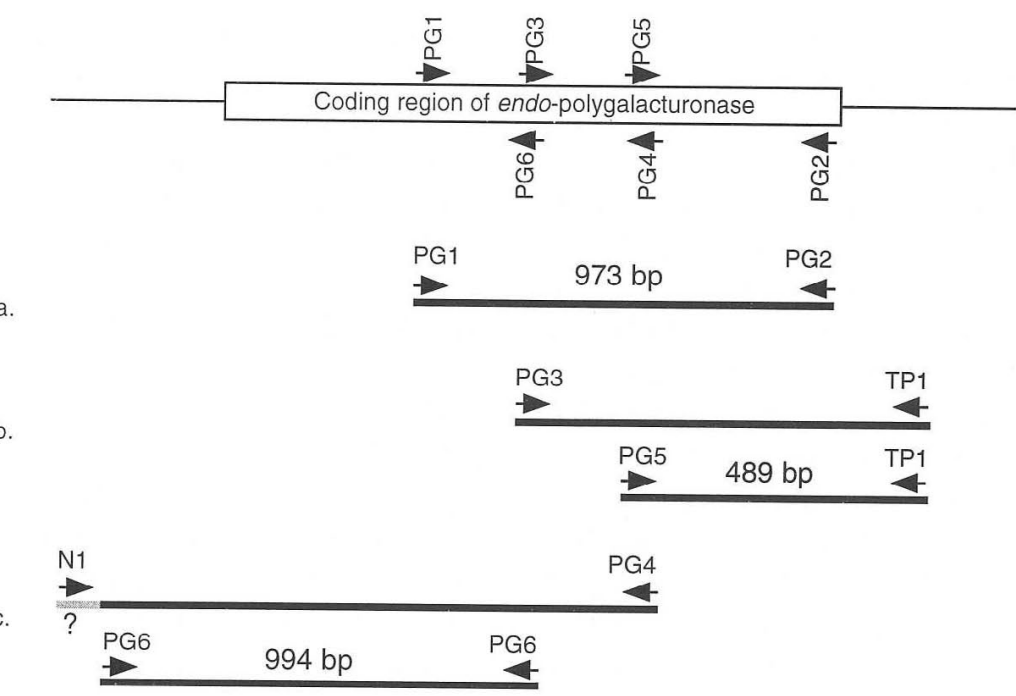

Fig. 1. Recovery of sequences of endopolygalacturonase (PG) by PCR and TAIL-PCR. (a) PCR with genomic DNA and primers PG1 +2 (Table 1) to get the 973 bp fragment of PG-encoding gene. (b) TAIL-PCR with genomic DNA and primers PG3 + TP1 (Table 1) generated a product that was used as a template in a second reaction with primer TP1 and nested primer PG5 (Table 1) to yield a $3^{\prime}$ fragment of $489 \mathrm{bp}$. (c) To obtain a sequence on the opposite side of the $973 \mathrm{bp}$ fragment, TAIL-PCR was done with genomic DNA and primers PG4+N1 (Table 1), which generated a product that was used as template in a second reaction with N1 and nested primer PG6 (Table 1), yielding a fragment of $994 \mathrm{bp}$. From the sequence data, we knew that the $994 \mathrm{bp}$ fragment was amplified with primers PG6 + PG6, suggesting that PG6 instead of N1 worked accidentally as an AD primer on the $5^{\prime}$ end in the second reaction (indicated with? in the figure).

Development Co., Shibuya, Tokyo). BLAST ${ }^{7}$ searches were done using the NCBI/GenBank databases.

\section{RESULTS AND DISCUSSION}

PG was purified from $5500 \mathrm{ml}$ of culture filtrate of $F$. oxysporum 880621a-1. The final $500 \mu 1$ fraction obtained through Sephadex G-75 containing $320 \mu \mathrm{g}$ protein $/ \mathrm{ml}$ was determined carrying $117.8 \mathrm{U} / \mathrm{mg}$ specific activity to release reducing sugar from polygalacturonic acid. The purification factor was 46.0 fold that of the original solution.

Polyclonal antibody designated as PAb APG1 raised against the purified $P G$ reacted positively with the $P G$ protein of $\sim 40 \mathrm{kD}$ in Western analysis of the PG protein (data not shown). Positive reaction with the antigenic solution was observed up to a 1000 fold dilution of the antibody by immunobinding assay. Its specificity toward F. oxysporum PG protein was apparent by its nonreaction with all fractions obtained during the $P G$ purifying procedure except for those containing PG-protein, and by its lack of cross reaction with the juice of tomato stem tissues and fruit.

By DT-IBA with PAb APG1, the stem sections of tomato plants infected with $F$. oxysporum 880621a-1 showed positive reaction (Fig. 2). Blue color was observed at the vascular system of the stem which confirms secretion of $\mathrm{PG}$ by $F$. oxysporum in the vessels of the host plant. This corresponds with Di Pietro's (1996) finding by isoenzymatic analysis ${ }^{6}$.

Through amino acid sequencing of Protease I-digested

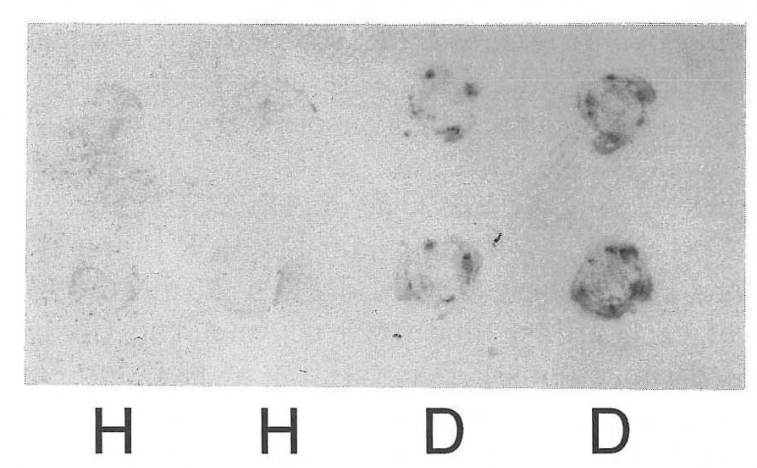

Fig. 2. DT-IBA of stems of tomato plants infected with Fusarium oxysporum f. sp. lycopersici race 2 880621a-1 with a polyclonal antibody APG1 raised against the purified endopolygalacturonase protein. D: stem sections from infected tomato plants with $F$. oxysporum; $\mathrm{H}$ : stem sections from tomato plants without infection. Positive reaction was observed at the vascular system of the infected samples.

PG protein 12 fragments (total 148 residues) were obtained, which helped us to design degenerate primers. $\mathrm{N}$-terminal amino-acid sequence was confirmed by sequencing of the undigested PG protein. In Fig. 3, Nterminal sequence is indicated by an underline and the partial amino acid sequences with bold characters.

Degenerate primers PG1 +2 (Table 1), designed using partial amino acid sequence data, were used for PCR with genomic DNA of $F$. oxysporum 880621a-1 as a template. Single unique DNA fragment of 973 bp, encod- 
ing a part of the PG gene was amplified (Fig. 1). Cloning and sequencing of this product revealed that it was homologous to a part of the previously reported PG gene of $F$. moniliforme ${ }^{5)}$.

To clone the adjacent fragments to either side of the
973 bp fragment, we performed TAIL-PCR (Fig. 1). In the primary TAIL-PCR reaction which was aimed to amplify sequences $5^{\prime}$ of the $973 \mathrm{bp}$ fragment, $\mathrm{AD}$ primer $\mathrm{N} 1$ and the fragment-specific primer PG4 (Table 1) were used with genomic DNA. Products of this reaction were

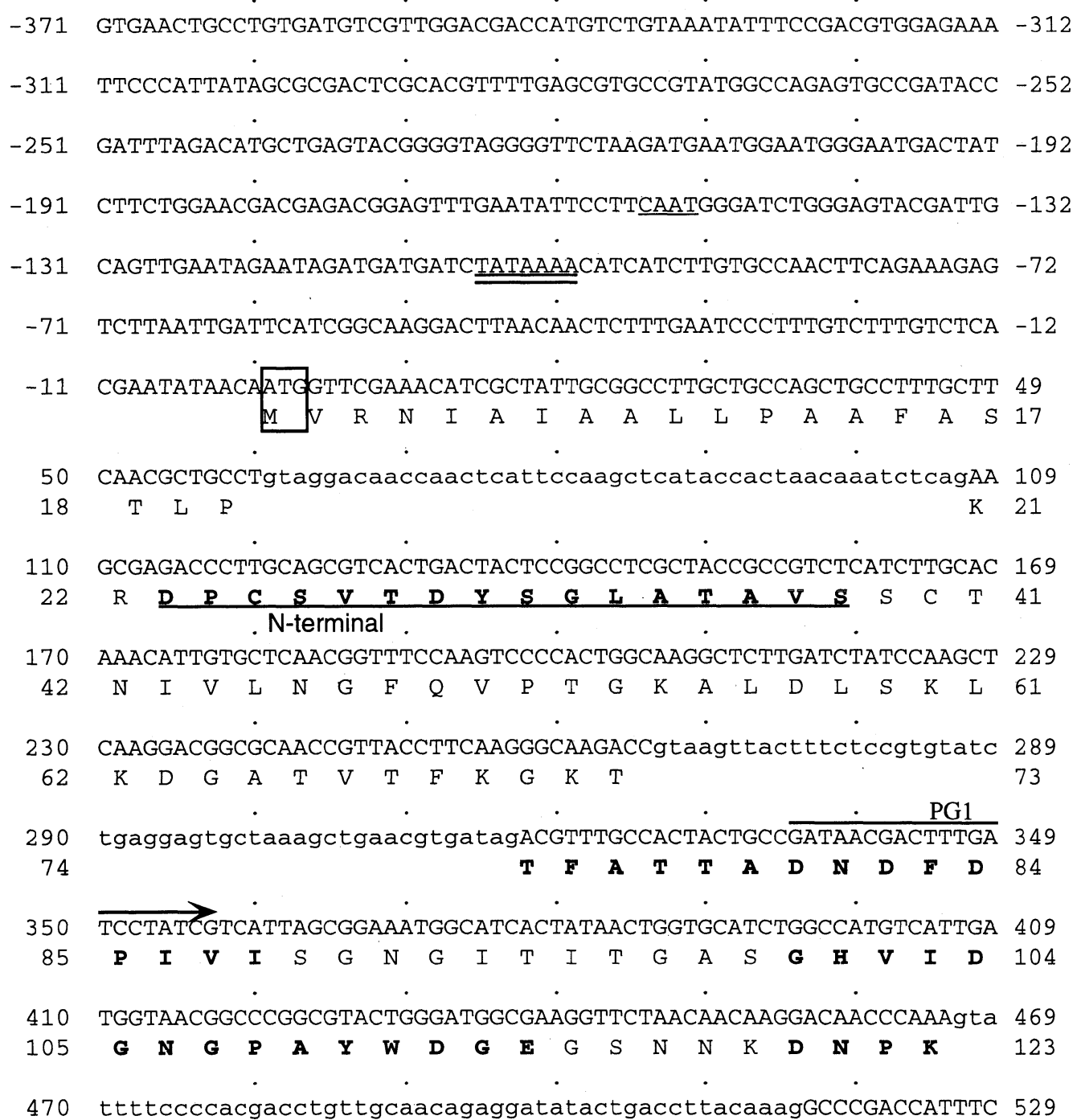

530 ATCGTTGTCAAGAAGACTACTGGCAACTCAAAGATCACAAACCTAAACATCCAGAATTGG 589

$\begin{array}{llllllllllllllllllllll}128 & \mathbf{I} & \mathbf{V} & \mathrm{V} & \mathrm{K} & \mathrm{K} & \mathrm{T} & \mathrm{T} & \mathrm{G} & \mathrm{N} & \mathrm{S} & \mathrm{K} & \mathrm{I} & \mathrm{T} & \mathrm{N} & \mathrm{L} & \mathrm{N} & \mathrm{I} & \mathrm{Q} & \mathbf{N} & \mathbf{W} & 147\end{array}$

590 CCCGTTCACTGCTTCGACATCACAGGCAGTTCACAATTGACCATCTCAGGGCTCATTCTT 649

$\begin{array}{llllllllllllllllllllll}148 & \mathbf{P} & \mathbf{V} & \mathbf{H} & \mathbf{C} & \boldsymbol{F} & \boldsymbol{D} & \boldsymbol{I} & \mathbf{T} & \mathrm{G} & \mathrm{S} & \mathrm{S} & \mathrm{Q} & \mathrm{L} & \mathrm{T} & \mathrm{I} & \mathrm{S} & \mathrm{G} & \mathrm{L} & \mathrm{I} & \mathrm{L} & 167\end{array}$

650 GATAACAGACTTGGCGACAAGCCCAATGCCAAGAGCGGTAGCTTGCCCGCTGCGCACAAC 709

$\begin{array}{llllllllllllllllllllll}168 & \mathrm{D} & \mathrm{N} & \mathrm{R} & \mathrm{L} & \mathrm{G} & \mathrm{D} & \mathrm{K} & \mathrm{P} & \mathrm{N} & \mathrm{A} & \mathrm{K} & \mathbf{S} & \mathbf{G} & \mathbf{S} & \mathbf{L} & \mathbf{P} & \mathbf{A} & \mathbf{A} & \mathbf{H} & \mathbf{N} & 187\end{array}$

710 AGCGACGGTTTCGACATCTCGTCCAGTGACCACGTTACTCTGGATAACATTCATGTTTAT 769

$\begin{array}{llllllllllllllllllllll}188 & \mathbf{S} & \mathbf{D} & \mathbf{G} & \mathbf{F} & \mathbf{D} & \mathbf{I} & \mathrm{S} & \mathrm{S} & \mathrm{S} & \mathrm{D} & \mathbf{H} & \mathbf{V} & \mathbf{T} & \mathbf{L} & \mathbf{D} & \mathbf{N} & \mathbf{I} & \mathbf{H} & \mathbf{V} & \mathrm{Y} & 207\end{array}$

770 AACCAGGATGACTGTGTTGCTGTCACTTCGGGTACAAACATCATCGTCTCCAACATGTAC 829

$\begin{array}{llllllllllllllllllllll}208 & \mathrm{~N} & Q & \mathrm{D} & \mathrm{D} & \mathrm{C} & \mathrm{V} & \mathrm{A} & \mathrm{V} & \mathrm{T} & \mathrm{S} & \mathrm{G} & \mathrm{T} & \mathrm{N} & \mathrm{I} & \mathrm{I} & \mathrm{V} & \mathrm{S} & \mathrm{N} & \mathrm{M} & \mathbf{Y} & 227\end{array}$

830 TGCTCCGGTGGTCATGGTCTTAGCATCGGATCTGTTGGCGGCAAGAGCAACAATGTCGTC 889

$\begin{array}{lllllllllllllllllllllll}228 & \mathbf{C} & \mathbf{S} & \mathbf{G} & \mathbf{G} & \mathbf{H} & \mathbf{G} & \mathbf{L} & \mathbf{S} & \mathbf{I} & \mathbf{G} & \mathbf{S} & \mathbf{V} & \mathbf{G} & \mathbf{G} & \mathbf{K} & \mathbf{S} & \mathbf{N} & \mathbf{N} & \mathbf{V} & \mathbf{V} & 247\end{array}$

Fig. 3 (1) 


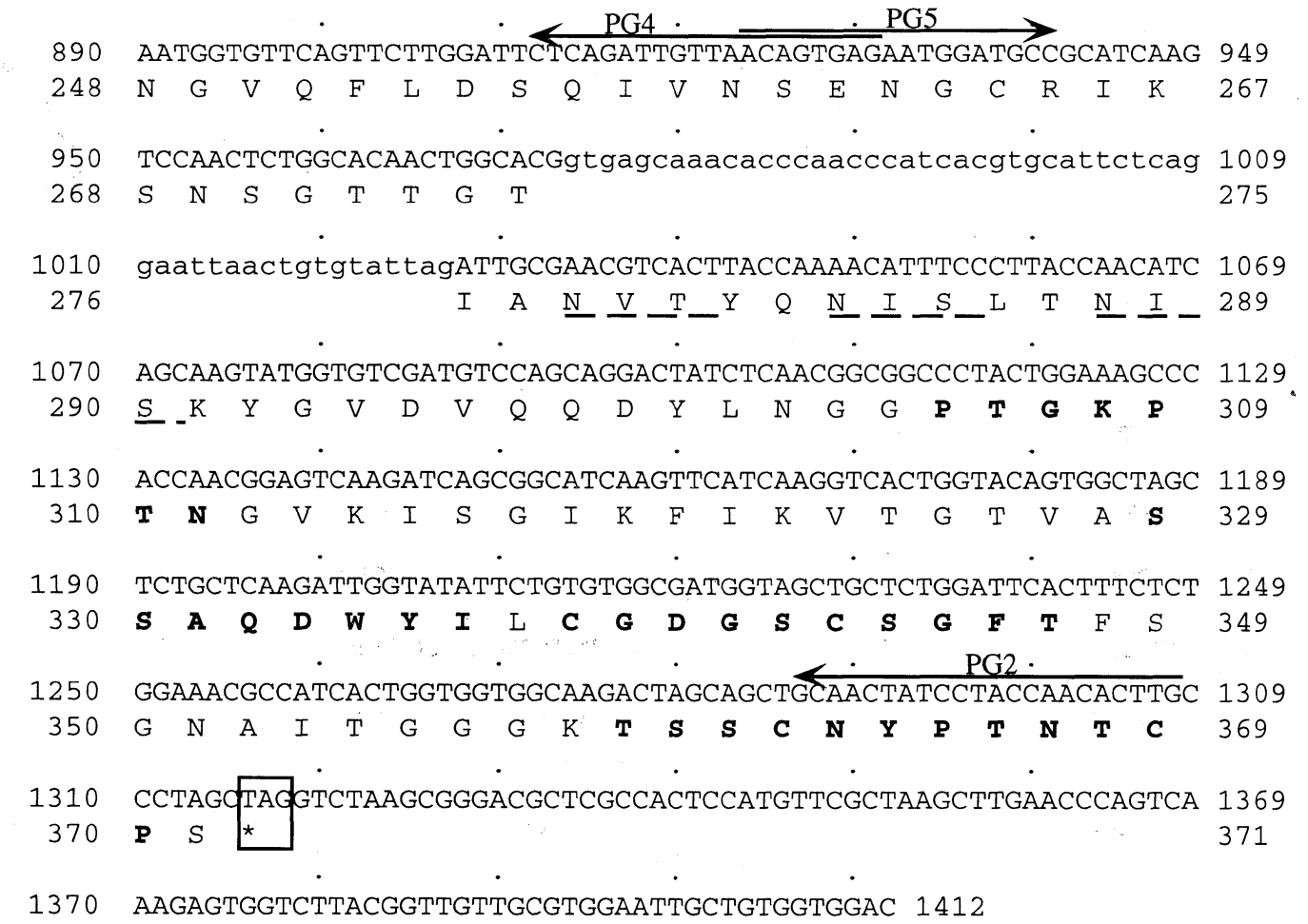

Fig. 3 (2)

Fig. 3. Nucleotide sequence of the endopolygalacturonase gene from Fusarium oxysporum f. sp. lycopersici race 2 880621a-1 and the predicted amino acid sequence of the encoded protein. Introns are shown with small letters. The amino acid sequence is shown in single-letter code below the corresponding codons. Determined amino acid sequences are indicated with boldfaces. The putative CAAT and TATA boxes in the promoter regions are single and double underlined, respectively. Putative $N$-glycosylation sites are underlined (dashed). The priming sites of PG1-6 primers are indicated with arrows.

used as templates in a second reaction with the same $\mathrm{AD}$ primer (N1) and a nested $973 \mathrm{bp}$ fragment-specific primer (PG6, Table 1), yielding a major product of 994 bp. From the sequence data, we knew that the $994 \mathrm{bp}$ fragment was amplified with primers PG6+PG6, suggesting that PG6 instead of N1 worked accidentally as an $\mathrm{AD}$ primer on the $5^{\prime}$ in the second reaction (Fig. 1).

An additional pair of reactions, designed to amplify sequences $3^{\prime}$ of the $973 \mathrm{bp}$ fragment, used $\mathrm{AD}$ primer TP1 (Table 1) and the fragment-specific primer PG3 (Table 1) for the first reaction and TP1 and specific primer PG5 (Table 1) for the second reaction, yielding a fragment of $489 \mathrm{bp}$. The $5^{\prime}$ end of the $994 \mathrm{bp}$ fragment and the $3^{\prime}$ end of the $489 \mathrm{bp}$ fragment were sequenced. Thus a total of 1783 bp sequence data was obtained (Fig. 3 ). The nucleotide sequence data presented will appear in the DDBJ, EMBL, and GenBank Nucleotide Sequence Database with the following accession number: AB000124 (submitted on Dec. 27, 1996).

The codon usage frequencies were A: 26.01\%, G: $23.11 \%, \mathrm{C}: 25.46 \%$, and $\mathrm{T}: 25.41 \%$ in the region.

The coding region consisted of $1318 \mathrm{bp}$ was interrupted by four putative introns of $47,51,50$, and $54 \mathrm{bp}$ (Fig. 3), which are at identical positions to that of $F$. moniliforme $\mathrm{PG}$ gene ${ }^{5)}$. The existence of the third intron was confirmed basing on the amino acid sequence data
(Fig. 3). The coding sequence comprised 371 amino acids with a putative signal peptide of 22 amino acids (MetArg). The molecular mass was calculated at 41,132.17 and $38,825.34$ with and without the 22 amino acids, respectively. The size was in good agreement with $40 \mathrm{kD}$ size determined by SDS-PAGE ${ }^{20}$. The $5^{\prime}$ region of the sequence contained a TATA motif (TATAAAA) at position -106 and a potential CAAT box (CAAT) at position $-155 \mathrm{bp}$. The sequence for initiation of translation (ACAATGG) was the same as that of $F$. moniliforme and highly homologous to the consensus sequence reported for higher eukaryotes ${ }^{11)}$.

The PG sequence was compared with other fungal PG sequences: $\mathrm{PG}$ from $F$. moniliforme ${ }^{5}$, PGNI from $C$. carbonum $^{19)}$, PG from A. nigar ${ }^{18)}$, PG from $A$. oryzae ${ }^{10)}$, and PGI from S. sclerotiorum ${ }^{16)}$ (Fig. 4). The deduced amino acid sequences are of similar sizes (from 362 to 380 aa). The $F$. oxysporum f. sp. lycopersici PG aa sequence showed $82.9,29.0,27.6,14.2$, and $26.9 \%$ identity to those of $F$. moniliforme PG, C. carbonum PGNI, $A$. niger $\mathrm{PG}, A$. oryzae $\mathrm{PG}$, and $S$. sclerotiorum $\mathrm{PGI}$, respectively.

The sequence of the amino acid residues of the $\mathrm{N}$-terminal of the PG shown in Fig. 3 was the same as that of the reported 11-residue sequence of the PG1, Asp-Pro-Cys-Ser-Val-Thr-Asp-Tyl-Ser-Gly-Leu ${ }^{6}$. 
FOIY MVRNI . AIAALLPAAFASTLPKRDPCSVTDYSGLATAVS . . . . . . . .

FMON MVRNIVSRLCSQLFALPSSSLQERDPCSVTEYSGLATAVS . . . . . . . .

CCar MVAYALTSMLGTTLDLTGLKSGATVLSAGALVAAAPSGLDARDG . CTF .

Anig MHSFASLLAGTTLDLTGLTSGTKVYGLAASATLASASPIEAR . GSCTF . •

Aory MQLLQSSVIAATV. GAALVAAVPVELKARDSCTFTSAADAKSG......

SSC1 MVHILSSALSLLRLGAAVSAAPAPAPTAANVADALAAVEKRAGSCTFSD

Foly ........... SCTNIVLNGFQVPTGKALDLSKLKDGATVTFKGKTTFA

Fmon ........... SCKNIVLNGFQVPTGKQLDLSSLQNDSTVTFKGTTTFA

CCar . TDAATAIKNKASCSNIVISGMTVPA.......... TFQGTTTFG

Anig . KTAAAAKAGKAGCSTITLDNIEVPA............. IFEGTTTFD

AorY .KT........SCSTITLSNIEVPAGETLDLTGLNDGTTVIFSGETTFG

SSC1 PAVPLPAIKSKASCATIVISAVAVPSGTTLDLTGLKSGTHVVFEGTTTFG

Foly TTADNDFDPIVISGNGITITGASGHVIDGNGPAYWDGEGSNNKDNPKPDH Fmon TTADNDFNPIVISGSNITITGASGHVIDGNGQAYWDGKGSNSNSNQKPDH Ccar YK. EWEGPLISVSGTNIKVVGASGHTIDAAGQKWWDGKGSNG. GKTKPKF Anig YE. EWAGPLISMSGKDITVTGASGHLINCDGARWWDGKGTS . . GKKKPKF AorY YK. EWEGPLISVSGTNIKVQQASGAKIDGDGSRWWDGKGGNG . GKTKPKF SSC1 TE. EWSGPLVSVSGTDITVTGASGSVLDGNGALYWDGKGTNG. GKTKPKF

FOlY FIVVKKTTGNSKITNLNIQNWPVHCFDITGSSQLTISGLILDNRLGDKPN Fmon FIVVOKTTGNSKITNLNIONWPVHCFDITGSSOLTISGLILDNRAGDKPN Ccar FYAHSLTT...SSISGLNIKNTPVQAFSINGVTGLTLDRITIDNSAGDS . . Anig FYAHGLDS...SSITGLNIKNTPLMAFSVQADD. ITLTDITINNADGDT. AorY FYAHKLDS..SSITGLQIYNTPVQGFSIQSDN. LNITDVTIDNSAG. T. . SSC1 FYAHSLK. GKSSINNVKILNSPVQVFSINSASGLTLSGITIDNSAGN . .

FOIY AKSGSLPAAHNSDGFDISSSDHVTLDNIHVYNQDDCVAVTSGTNIIVSNM FMON AKSGSLPAAHNTDGFDISSSDHVTLDNNHVYNQDDCVAVTSGTNIVVSNM CCar .......AGAHNTDAFDIGSSSGITISNANI KNQDDCVA INSGSDIHVTNC Anig . . . L. LGHNTDAFDVGNSVGVNI I K PWVHNQDDCLA IN S GENIWFT SG AorY ...... AEGHNTDAFDVGSSTYINIDGATVYNQDDCLAINSGSHITFTNG SSC1 ....SL. . GHNTDAFDVGSSTDITISGANVQNQDDCLAINSGTGITFTGG

FOIY YCSGGHGLSIGSVGGKSNNVVNGVQFLDSQIVNSENGCRIKSNSGTTGTI FmOn YCSGGHGLSIGSVGGKSDNVVDGVOFLSSOVVNSONGCRIKSNSGATGTI Ccar QCSGGHGVSIGSVGGRKDNTVKGVVVSGTTIANSDNGVRIKTISGATGSV Anig TCIGGHGLSIGSVGGR SNNVVKNVTIEHSTVSNSENAVRIKTVSGATGSV AOrY YCDGGHGLSIGSVGGRSDNTVEDVTISNSKVVNSONGVRIKTVYDATGTV SSCI TCSGGHGLSIGSVGGRSDNVVSDVIIGSSTVKNSANGVRIKTVSGATGSV

FOIY ANVTYQNISLTNISKYGVDVQQDYLNGGPTGKPTNGVKISGIKFIKVTGT FmOn NNVTYQNIALTNISTYGVDVQQDYLNGGPTGKPTNGVKISNIKFIKVTGT

Ccar SDITYENITLKNIAKYGIVIEQDYLNGGPTGKPTTGVPITGVTLKNVAGS Anig SEITYSNIVMSGISDYGVVIQQDYEDGKPTGKPTNGVTITDVKLESVTGT AorY SNVKFEDITLSGITKYGLIVEQDYENGSPTGTPTNGIKVSDITFDKVTGT SSC1 SGVTYKDITLSGITSYGVVIEQDYENGSPTGKPTSGVPITGVTLSNVHGT

FOIY VA.SSAQDWYILCGDGSCSGFTFSGNAITGGGKTSS . C NYPTNT . CPS FmOn VA.SSAQDWFILCGDGSCSGFTFSGNAITGGGKTSS.C. NYPTNT. CPS

CCar VT.GSGTEIYVLCGKGSCSGWNWSGVSITGGKKSSS.CLNVPSGASC

Anig VD.SKATDIYLLCGSGSCSDWTWDDVKVTGGKKSTA.CKNYPSVASC

AOrY VVESDATDIYILCGSGSTGLTWSG.SITGG. KTSSKCENVSTGASC

SSCI VS.SSATNVYVLCAK . CSGWTWDVN. VTGG. KTSTKCAGLPSGVKC

Fig. 4. Comparison of the deduced amino acid sequence. The deduced amino acid sequence of the PG of Fusarium oxysporum f. sp. lycopersici race 2 880621a-1 (Foly) was compared with the PG of F. moniliforme (Fmon) (Caprari et al., 1993), PGNI of Cochliobolus carbonum (Ccar) (Scott-Craig et al., 1990), PG of Aspergillus niger (Anig) (Ruttkovski et al., 1991), PG of A. oryzae (Aory) (Kitamoto et al., 1993), and PGI of Sclerotinia sclerotiorum (Sscl) (Reymond et al., 1994). Gaps were introduced into the sequences to achieve optimal alignment and are represented by dots. Amino acid residues identical to the F. oxysporum PG are shown in bold letters.

Kitamoto et al. $(1993)^{10)}$ reported the presence of three regions with conserved amino acid sequences for various PGs. Caprari et al. $(1993)^{5)}$ reported a fourth region. We could confirm these sequences (Asn ${ }^{187}-S^{196}$, Asn ${ }^{208}$.
$\mathrm{Ala}^{214}, \mathrm{Gly}^{231}-\mathrm{Ser}^{238}$, and $\mathrm{Ser}^{260}-\mathrm{Ser}^{268}$ ) in $F$. oxysporum, and additionally found a region at $\mathrm{Gln}^{298}-\mathrm{Il}^{315}$ that is highly maintained among the species (Fig. 4). This suggests that these domains possibly are of some enzymatic 


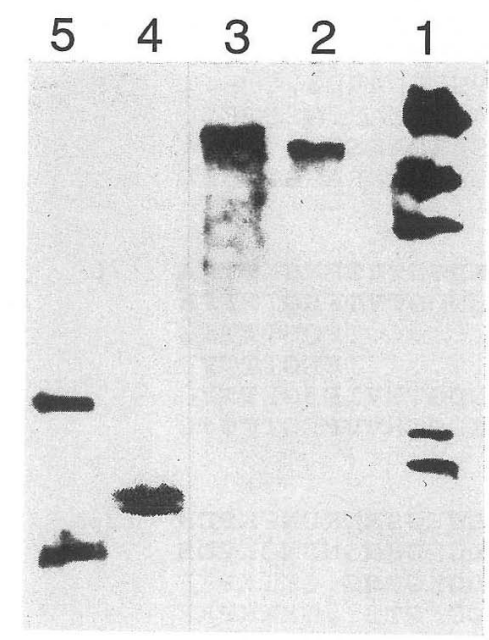

Fig. 5. Genomic Southern hybridization of digested genomic DNA of Fusarium oxysporum f. sp. lycopersici race $2880621 \mathrm{a}-1$. gDNA was digested with EcoRI (no site on PG encoding region), Bam HI (no site), BanII (one site), and HincII (one site), respectively, and separated in a $0.8 \%$ agarose gel to blot and probed with the cloned $973 \mathrm{bp}$ fragment amplified with PG1+PG2 primers. Lane 1: $\lambda$ HindIII marker; Lane 2: gDNA/EcoRI ; Lane 3 : gDNA/Bam HI ; Lane 4: gDNA/BanII, Lane 5: gDNA/HincII. Note that just one band was detected from the gDNA digested with EcoRI and BamHI, and two bands were from the gDNA digested with BanII and HincII.

importance such as catalysis or substrate binding.

Three potential $N$-glycosylation sites (Asn-Xaa-Thr/ Ser) were found (indicated with dashed underlines in Fig. 3). Although two of them $\left(\mathrm{Asn}^{278}-\mathrm{Val}-\mathrm{Thr}^{280}\right.$ and $\mathrm{Asn}^{288}$. Ile-Ser ${ }^{290}$ ) corresponded to those of $F$. moniliforme PG, the sites were not conserved among the species. The existence of these potential $N$-glycosylation sites is in agreement with the observation of PG1 and the other $N$-glycosylated isoforms ${ }^{6}$. There is no enzymatic information, such as its kinetics and substrate-specificity for the isoforms.

gDNA of $F$. oxysporum digested with EcoRI (having no site on the PG encoding region), Bam HI (no site), BanII (having one site at $638 \mathrm{bp}$ ), and HincII (having one site at $920 \mathrm{bp}$ ) were probed with the pCR2.1 carrying the 973 bp PCR product amplified with PG1+PG2. Only one hybridizing band appeared in the $F$. oxysporum gDNA digested with Eco RI and Bam HI, respectively, and two bands in the gDNA digested with BanII and HincII (Fig. 5). According to the results of genomic Southern hybridization, $F$. oxysporum f. sp. lycopersici has one PGencoding gene on its genome.

The facts such as $F$. oxysporum being an inhabitant of the vessels ${ }^{2)}$ and the specific induction of PG protein in the presence of pectin or plant tissue ${ }^{6,20)}$, coupled with our DT-IBA result showing PG protein secretion in the vessels of tomato stems, strongly suggest that PG has some role in disease development.

To understand the infection mechanism of $F$. oxysporum clearly, pectinolytic enzymes have been the subject of enzymatic investigations. However, when and how the enzyme-coding genes are induced and the proteins secreted is still unclear, even in the recent isoenzymatic study by Di Pietro and Roncero (1996) ${ }^{6}$.

Our final goal is to know when PG is expressed, if it is essential to symptom development, and/or whether $\mathrm{PG}$ is the determining factor in the f. sp.-host specificity. Towards that purpose, the existence of a single copy of the PG gene presents good candidate for gene disruption, in order to evaluate its importance during symptom development. A genetical knockout study of the PG gene in $C$. carbonum has already disproven its role in causing disease on maize ${ }^{19)}$. Still, studying the role of $\mathrm{PG}$ of $F$. oxysporum is worthwhile, considering the great emphasis given to this protein's role in tomato wilt disease by many workers.

Among the phytopathogenic species of $F$. oxysporum, many pathogenic formae speciales ${ }^{4)}$ with high host specificity have been reported. Although IEF patterns showed no difference between the isoenzymes of $F$. oxysporum ff. sp. lycopersici and cucumerinum ${ }^{3)}$, knowing the differences in the nucleotide and/or amino acid sequences between formae and whether the formae have different PG gene induction on different plants is still of interest.

In addition, many non-pathogenic $F$. oxysporum strains $^{4,15)}$ have been reported and used as biological control agents. Do those non-pathogenic strains have a PG encoding gene? If they have, PG may have no role in the induction of symptoms or, the critical point in determining susceptibility to $F$. oxysporum occurs before the PG is secreted.

The authors gratefully acknowledge Mr. T. Shimizu, RIKEN for helping in DNA sequencing and growing plants.

\section{Literature cited}

1. Arie, T., Christiansen, S.K., Yoder, O.C. and Turgeon, B.G. (1997). Efficient cloning of Ascomycete mating type genes by PCR amplification of the conserved MAT HMG box. Fungal Genet. Biol. 21 : 118-130.

2. Arie, T., Hayashi, Y., Yoneyama, K., Nagatani, A., Furuya, M. and Yamaguchi, I. (1995). Detection of Fusarium spp. in plant with monoclonal antibody. Ann. Phytopathol. Soc. Jpn. 61 : 311-317.

3. Arie, T., Shimazaki, S., Inoue, M., Yoneyama, K. and Yamaguchi, I. (1993). Polygalacturonase produced by Fusarium oxysporum f. sp. lycopersici 880621a-1 (Abstr. in Japanese). Ann. Phytopathol. Soc. Jpn. 59 : 734.

4. Beckman, C.H. (1987). The Nature of Wilt Diseases of Plants, APS Press, St. Paul, Minnesota, pp. 145-148.

5. Caprari, C., Richter, A., Bergmann, C., Locicero, S., Cervone, F. and De Lorenzo, G. (1993). Cloning and characterization of a gene encoding the endopolygalacturonase of Fusarium moniliforme. Mycol. 
Res. $97:$ 497-505.

6. Di Pietro, A. and Roncero, M.I.G. (1996). Endopolygalacturonase from Fusarium oxysporum f. sp. lycopersici: Purification, characterization, and production during infection of tomato plants. Phytopathology 86 : $1324-1330$.

7. Gish, W. and States, D.J. (1993). Identification of protein coding regions by database similarity search. Nat. Genet. 3 : 266-272.

8. Gross, E. (1967). The cyanogen bromide reaction. Methods Enzymol. 11 : 238-255.

9. Hirs, C.H.W. (1967). Reduction and S-carboxymethylation of proteins. Methods Enzymol. 11: 199-203.

10. Kitamoto, N., Kimura, T., Kito, Y., Ohmiya, K. and Tsukagoshi, N. (1993). Structural features of a polygalacturonase gene cloned from Aspergillus oryzae KBN616. FEMS Microbiol. Lett. 111 : 37-41.

11. Kozak, M. (1981). Composition and analysis of sequences upstream from the translocational start site in eukaryotic mRNAs. Nucleic Acids Res. 12: 857-872.

12. Kumar, C.R. and Subramanian, D. (1979). Studies on Fusarium wilt of cotton II. The role of pectolytic enzymes. Phytopathol. Z. 94 : 343-356.

13. Liu, Y.G. and Whittier, F. (1995). Thermal Asymmetric Interlaced PCR: Automatable amplification and sequencing of insert end fragment from P1 and YAC clones for chromosome walking. Genomics 25 : 674-681.

14. Masaki, T., Tanabe, M., Nakamura, K. and Soejima, M. (1981). Studies on a new proteolytic enzyme from Achromobacter lyticus M497-1, I. Purification and some enzymatic properties. Biochim. Biophys. Acta 660 : 4450.

15. Ogawa, K. and Komada, H. (1985). Biological control of Fusarium wilt of sweet potato with cross-protection by nonpathogenic Fusarium oxysporum. In Ecology and Management of Soilborne Plant Pathogens (Parker, C.A. et al. eds.), Amer. Phytopathol. Soc., St. Paul, Minnesota, pp. 121-123.

16. Reymond, P., Deleage, G., Rascle, C. and Fevre, M. (1994). Cloning and sequence analysis of a polygalacturonase-encoding gene from the phytopathogenic fungus Sclerotinia sclerotiorum. Gene 146 : 233-237.

17. Reymond-Cotton, P., Fraissinet-Tachet, L. and Fevre, M. (1996). Expression of the Sclerotinia sclerotiorum polygalacturonase $p g 1$ gene: possible involvement of CREA in glucose catabolite repression. Curr. Genet. 30 : 240-245.

18. Ruttkovski, E., Khanh, N.Q., Wientjes, F.J. and Gottschalk, M. (1991). Characterization of a polygalacturonase gene of Aspergillus niger RM5344. Mol. Microbiol. $5: 1353-1361$.
19. Scott-Craig, J.S., Panaccione, D.G., Cervone, F. and Walton, D.J. (1990). Endopolygalacturonase is not required for pathogenicity of Cochliobolus carbonum on Maize. Plant Cell 2: 1191-1200.

20. Shimazaki, S., Arie, T., Yoneyama, K., Takio, K. and Yamaguchi, I. (1994). Purification, amino acid analysis of polygalacturonase produced by Fusarium oxysporum f. sp. lycopersici race 2 and its antibody preparation. Ann. Phytopathol. Soc. Jpn. 60 : 751 (Abstr. in Japanese).

21. Szecsi, A. (1990). Analysis of pectic enzyme zymograms of Fusarium species. II. Comparison of polygalacturonase zymograms of Fusarium culmorum and Fusarium graminearum. J. Phytopathol. 130 : 180196.

22. Whitehead, M.P., Shieh, M.T., Cleveland, T.E., Cary, J.W. and Dean, R.A. (1995). Isolation and characterization of polygalacturonase genes ( $p e c A$ and $p e c B$ ) from Aspergillus flavus. Appl. Environ. Microbiol. 61: 33163322.

23. Wirsel, S., Turgeon, B.G. and Yoder, O.C. (1996). Detection of the Cochliobolus heterostrophus mating-type $(M A T)$ locus promotes the function of MAT. Curr. Genet. $29: 241-249$.

\section{和 文 摘 要}

有江 力 - Satyanarayana GouTHU - 島崎 聡 - 鎌倉高志 木村 真 - 井上美津子 ・ 瀧尾擴士 ・ 尾崎 明 - 米山勝美 ・山口 勇：Fusarium oxysporum の植物組織中におけるエンドポリガ ラクツロナーゼの分泌の免疫学的観察と本酵素をコードする遺 伝子の単離

土壤病原糸状菌 Fusarium oxysporum の産生するエンドポリ ガラクツロナーゼ (PG) は, 病徴発現において重要な役割を果 たすといわれている。精製したトマト萎调病菌（F． oxysporum f. sp. lycopersici race 2) 由来の PG タンパク質を抗原としてポ リクローナル抗体 APG1 を作製し, これを用いて direct tissueimmunobinding assay (DT-IBA) 法により, 寄主植物の茎中で F. oxysporum f. sp. lycopersici が PG を産生していることを認 めた。また, PG タンパク質のアミノ酸解析により得られた部分 アミノ酸配列情報をもとにプライマーをデザインし, PCR と TAIL-PCR により, PG をコードする遺伝子の全長を含む 1783 bp の塩基配列を決定した。PG 遺伝子は，47, 51, 50, 54 bp の 4 つのイントロンを含む $1318 \mathrm{bp}$ のコード領域からなり, $371 ア$ ミノ酸残基をコードし, このうち, 22 残基はシグナルペプチド であることが推測された。アミノ酸レベルで，F. moniliforme PG, Cochliobolus carbonum PGNI, Aspergillus niger PG, A. oryzae PG および Sclerotinia sclerotiorum PGI とそれぞれ, $82.9 \%, 29.0 \%, 27.6 \% ， 14.2 \% ， 26.9 \%$ の相同性を示した。 